\title{
BOOK Indústria de notícias: REVIEW \\ capitalismo e \\ novas techologias \\ no jornalismo \\ contemporâneo \\ (News Industry: Capitalism and new technologies in contemporary journalism) \\ Virginia Pradelina da Silveira Fonseca \\ Porto Alegre: Editora da UFRGS, 2008. 310 pgs.
}

Reviewed by Thais de Mendonça Jorge

\section{THE NEWS}

\section{Where have we come from? Where are we going?}

It seems that a basic, prosaic question was worrying the author, even before she thought of doing a doctorate thesis, a question which is the basis for many people interested in understanding today's world, people who are currently doing other masters and doctorate theses, for whom the important position of the media nowadays is truly a preoccupying topic. What is news? This question would be the leitmotiv underlying the courageous research which Virginia Pradelina da Silveira Fonseca has undertaken with regard to journalism's trajectory under the capitalist system, in order to discover where we have come from and where we have arrived.

The thesis was the winner of the Capes Award in the area of Applied Social Sciences in 2006, with the original title of $O$ Jornalismo no conglomerado de mídia: reestruturação produtiva sob o capitalismo global (Journalism in the media conglomeration: production restructuring under global capitalism). For editorial reasons, it became Indústria de notícias: capitalismo e novas tecnologias no jornalismo contemporâneo (News industry: capitalism and new technologies in contemporary journalism), a name which doubtlessly better expresses the results which 
the author obtained in her academic work. We are really in a period of mass production of news, as in a factory or in the post-Fordian assembly line which Fonseca points to, and the objective of this great network, for which the electronic machines supply the power, is profit.

We could divide the book into two parts: 1) theoretical, in which the author explains Political Economy of Communication and provides a historical account of capitalism 's influence in modern society, especially in the informative industries; 2 ) empirical, which deals with the research strictly speaking with respect to the Rede Brasil Sul - RBS (South Brazil Network). One of the first important evaluations is exactly what is journalism, "a social activity (...) given a variable historical concept according to the period and which can be structured in a regular way in the most diverse means of communication, from the press to television", which is not to be confused with printing, since "the existence of printing is not sufficient to guarantee the presence of a concept of journalism". Journalism is rather an "element of the public sphere in which there is established the agenda of the matters around which the phenomenon called public opinion is structured" (Rudiger, 2003).

If the conception of journalism as news is a recent phenomenon, "from mid-20th century", making up part of the media modernization process which began in 1950 and was intensified starting in 1960, as the author discovers, it would have a short life. Starting in 1995, with the entrance on the stage of new actors - the information and communication technologies - the news would lose its public service nature, satisfying the public's need to be informed, and would be closer to mathematical information, numerical or binary, a merchandise which could be measured, weighed, quantified, optimized and in this way, sold. Produced in plants with pipes and turbines, the news could be stored and released in accordance with industrial strategies, and not in accordance with the citizen's right to get to know what is happening, or entrusted with being the eyes of society in the overseeing of the public authorities.

In the Political Economy of Communication hypothesis, the changes in the media's organizational structures, in the production routines and in the journalists' professional culture are attributed to the stages of capitalist development through which the information companies in the world and in Brazil have passed and are passing. In the early 1960s, the call for "modernization of the press" was heard in Brazil, when the print media - displaying the structures of the previous century - underwent graphic and editorial reforms in order to adapt to the new post-war period, under great influence from the American press, the institution of the first 
manuals and of a standardization of the news in the newsrooms. In the monopolistic stage of Fordian influence, Fonseca says, the newspaper product and journalistic information have taken on the characteristic of merchandise, although they have preserved the political purpose of journalism - "the content prevails, characterizes, defines the newspaper and sustains its interest in the eyes of the public".

What has happened in the third world countries was a delayed entrance into the international capitalist economy, caused by the military dictatorships of the period 1960-1990. In the communication companies of that Fordian stage, the functions are positions occupied by a person, in a system of division of the work and specialization of tasks. However, in the post-Fordian stage which the companies have already attained in the globalization process and as a result of the "revolution in the information technologies", the changes have not been restricted to the companies" internal life. The companies are beginning to transform themselves into international conglomerates, which in Brazil was made possible by the amendment to article 222 of the 1988 Constitution, permitting the participation of foreign capital in the radio and TV journalistic sector.

In 1988, in Porto Alegre, a radical transformation took place in the panorama of the press - and only those who lived through this period could understand. Fonseca was a witness: "The old sheets of paper and typewriters which, with the traditional cigarette smoke, made up the polluted work environment were replaced by computer terminals equipped with software for editing text and desktop publishing installed in a clean air-conditioned environment on a floor high above Avenida Ipiranga." The computerization of the Zero Hora newsroom was the first one to happen in the country and marked not only the entrance into a post-Fordian stage, but also the era of multimedia information in the country, with new concepts of news, multiple functions for the journalist and doubts relating to professional ethics and culture.

The daily Zero Hora, the focus of Virginia Fonseca's research, and the RBS are successful companies in the communication area, with 880 journalists who periodically undergo multimedia training, including study overseas with scholarships from the company. The tasks which these new journalists perform would be better classified as roles which they play, in the McCluhan sense (Mother is a role, not a function): the professionals do not earn any more for covering the same event for various media, but they have the feeling that they are holding on to their jobs better.

And the news, where does the news come in? The author replies: "The transformation of information - not necessarily that which has journalistic 
attributes - into a commodity, while contrary to the principles of journalism, is coherent with the dominant logic in (...) informational capitalism". This new trend which she identifies in the media conglomerates, in this stage of capitalism more concerned with the profitable company than with journalism itself, would have as a characteristic "the decline of the news as an expression of journalism in favor of information, of service performance and of entertainment (fait- divers)".

Thais de Mendonça Jorge holds a doctorate in Communication from the University of Brasília, and is currently in Post-Doctorate residence at the University of Navarra, Spain, with a scholarship under the CapesDGU agreement. 